\title{
Applying the Access Principle in Law: The Responsibilities of the Legal Scholar*
}

\author{
RICHARD A. DANNER ${ }^{* *}$
}

This article discusses the responsibilities of legal scholars to make their published works openly accessible through the Internet, within the context of efforts to increase free and open access to legal information, and to improve access to scholarly literature in other disciplines. The article also considers the roles and responsibilities of the institutions that support the creation and communication of legal scholarship for improving access to legal information.

\section{INTRODUCTION: THE ACCESS PRINCIPLE}

At a symposium on open access to law in the fall of 2006, ${ }^{1}$

* Richard A. Danner (C) 2008. Based on papers presented at the program: “Open Access Law, Free Legal Information, Democracy, and Human Rights” at the IFLA General Conference Council 73rd World Library \& Information Congress, Durban, South Africa, August 19, 2007; and at the Starr Workshop on Tapping into the World of Electronic Legal Knowledge, Cornell Law Library, Ithaca, N.Y., U.S.A., October 10, 2007.

${ }^{* *}$ Rufty Research Professor of Law and Senior Associate Dean for Information Services, Duke Law School, Durham, N.C., U.S.A. Thanks to Amanda Barratt, James Boyle, Michael Carroll, Tom Bruce, Gene Koo, Terry Martin, and John Willinsky for their comments on earlier versions of this article, and to Katherine Topulos for her research assistance.

${ }^{1}$ A generally-accepted definition of open access is that of the 2002 Budapest Open Access Initiative, which defines open access in reference to scientific and scholarly research as:

free availability on the public internet, permitting any users to read, download, copy, distribute, print, search, or link to the full texts of these articles, crawl them for indexing, pass them as data to software, or use them for any other lawful purpose, without financial, legal, or technical barriers other than those inseparable from gaining access to the internet itself.

Budapest Open Access Initiative: Frequently Asked Questions: Open Access (last revised, Jan.31, 2008), http://www.earlham.edu/ peters/fos/boaifaq.htm\#openaccess.

Another commentator suggests that any strict definition of open access may be too limiting: "Only by working with a loosely defined approach to open access 
Michael Carroll of the Villanova Law School discussed the linkages between the movement for open access to research and scholarly literature in the sciences and other disciplines, and the movement for free access to law, which has focused on cases, statutes, and other materials issued by bodies with law-making authority. ${ }^{2}$ Arguing for the importance of open access to legal scholarship as well as to the documents produced by courts, legislatures and other authorities, Carroll writes: "Access to law matters. . . . access to legal scholarship matters too." 3 He notes not only the benefits that will accrue to legal scholars who make their work accessible on the public internet, but the improvements in scholarly communication that will result:

- maximizing the impact of individual scholarship

- reaching audiences without access to commercial databases

- improving interdisciplinary dialogue

- improving international impact and dialogue ${ }^{4}$

In his discussion of "serving the underserved"-those without access to commercial sources of legal information, Carroll suggests that, in addition to the benefits they confer, new communications technologies also create for the scholar "a duty to make his or her work available to the general (or, for the time-being, Internet-accessible) public."

The idea that scholars have a responsibility to make their work widely available through open access mechanisms is developed and argued by John Willinsky in his 2006 book: The Access Principle: The Case for Open Access to Research and Scholarship. ${ }^{6}$ Willinsky's access principle states that "A

archiving and publishing can one begin to capture the variety of and variation in the means that are now being used to increase access to scholarship and research.” John Willinsky, The Access Principle: The Case for Open Access to Research and Scholarship 211 (2006). Willinsky presents ten "flavors" of open access based on financing and the kind of access they provide. Id. at 211-216.

${ }^{2}$ On the open access movements in law and in other disciplines, see infra Section II.

${ }^{3}$ Michael W. Carroll, "The Movement for Open Access Law," 10 Lewis and Clark L. Rev. 741, 743 (2006).

${ }^{4}$ Id. at 755-757. On impact, see also Willinsky, supra note 1, at 22 (noting that the "research impact" of a work includes not only its impact on the work of others, but its contribution to the author's reputation).

${ }^{5}$ Carroll, supra note 3, at 756 (emphasis added).

${ }^{6}$ The full text of the book can be downloaded in PDF format without charge at: http://mitpress.mit.edu/catalog/item/ebook.asp?ttype=2\&tid=10611 (last visited Feb.18, 2008). Willinsky is the Pacific Press Professor of Literacy Technology at the 
commitment to the value and quality of research carries with it a responsibility to extend the circulation of such work as far as possible and ideally to all who are in interested in it and all who might profit by it." "7 For Willinsky, the transformation of journal formats from print to online means that not only researchers and scholars, but "scholarly societies, publishers, and research libraries have now to ask themselves whether or not they are using this new technology to do as much as they can to advance and improve access

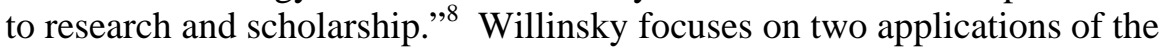
access principle that have potential importance in law: 1) making research and scholarship available to the public as well as to specialized academic audiences, and 2) improving the capabilities of researchers throughout the world to contribute to the development of knowledge in their fields.

For Willinsky, "open access is also public access." ${ }^{9}$ He analogizes twenty-first century web access to research literature to the nineteenth century public library movement in the United States, noting the widespread public interest in web-accessible health and environmental information. ${ }^{10}$ After presenting his examples, however, he concludes that "proving that the public has sufficient interest in, or capacity to understand, the results of scholarly research is not the issue. The public's right of access to this knowledge is not something that people have to earn. It is grounded in the basic right to know." 11 In law, it can be argued as well that scholars have a particular responsibility to make their work available because of the impact of law on the daily lives of the public, and the influences of legal scholarship on those who make the laws. As put by Carroll: "If acted upon, the ideas we develop,

University of British Columbia, and Professor of Education at Stanford University. He is the founder and principal investigator for the Public Knowledge Project (PKP), a partnership of several institutions "dedicated to exploring whether and how new technologies can be used to improve the professional and public value of scholarly research,” http://pkp.sfu.ca/about (last visited Feb. 18, 2008). Among other products, PKP has developed free open source journal publishing software, Open Journal Systems (OJS), which is used by over 900 journals publishing in ten languages. See Open Journal Systems, http://pkp.sfu.ca/?q=ojs (last visited Feb. 3, 2008). The OJS software is used by African Journals Online (AJOL), http://www.ajol.info/ (last visited Feb. 18, 2008). AJOL is discussed infra, text accompanying note 143.

${ }^{7}$ Willinsky, supra note 1 , at xii (emphasis omitted).

${ }^{8}$ Id.

${ }^{9}$ Id. at 111 .

${ }^{10} \mathrm{Id}$. at $112-120$.

${ }^{11}$ Id. at 125. 
and the arguments we make, affect the interests and rights of members of the public."12

Willinsky suggests that open access publishing models hold promise "for broadening the circulation and exchange of knowledge ... [and] of moving knowledge from the closed cloisters of privileged, well-endowed universities to institutions worldwide." ${ }^{13}$ He uses the work of philosopher of science Helen Longino to argue that "the global scale of knowledge's circulation is critical to its very claim as knowledge," 14 and echoes Colin Darch's 1998 comments regarding whether the developed countries of the North will "continue to refuse to cooperate in the establishment of an equitable world information order, based on entrenched principles of full disclosure and free flow." ${ }^{15}$ For Willinsky, open access publishing systems, installed and managed locally, but providing searchable global access to their contents, will provide greater visibility for scholarship produced in developing countries, thereby holding the promise for greater intellectual autonomy for scholars everywhere and the opportunity for all to participate on an equal basis with others in their field. ${ }^{16}$ The access principle thus calls not only for a freer flow of information from developed to developing nations, but (and more importantly in the long term), for creating the means for scholars everywhere to contribute to the discourse of their discipline.

If Willinsky is correct in his point that the responsibilities of the access principle should be taken seriously by all participants in the scholarly communications process, it is important then to consider how to implement them. In law, those discussions must include not only the responsibilities of

\footnotetext{
${ }^{12}$ Carroll, supra note 3, at 756. A well-attended session at the 2008 annual meeting of the Association of American Law Schools featured a panel of legal scholars offering examples of what law faculty could do to promote and facilitate the implementation of their ideas beyond the academy. The description for the program: “Implementing Scholarship” is available at: http://www.aals.org/am2008/saturday/ index.html (last visited Feb. 18, 2008). See also David Hricik \& Victoria S. Salzmann, "Why There Should be fewer Articles Like This One: Law Professors Should Write More for Legal Decision-Makers and Less for Themselves,” 38 Suffolk U. L. Rev. 761 (2005).

${ }^{13}$ Willinsky, supra note 1 , at 33

${ }^{14} \mathrm{Id}$. at 34 (emphasis in original).

${ }^{15}$ Id. at 94, quoting Colin Darch, The Shrinking Public Domain and the Unsustainable Library 12 (1998) (Paper presented at the conference on the Electronic Library: Gateway to Information: Resource Sharing and User Services in the Electronic Library, Lund, Sweden, 2-6 June 1998) (on file with author).

${ }^{16} \mathrm{Id}$. at $104-105$.
} 
the creators of legal scholarship, but also those of institutions that support their work. What should law schools, law librarians and information technologists do to ensure that legal scholarship is as widely accessible as possible? What means are available for making this literature freely and openly accessible? This article is intended to explore the implications of applying the access principle in law.

Section II introduces the movements for open access to law and to scholarship in other disciplines. Section III addresses the value of open access to the legal journal literature. Sections IV and V discuss means for enabling access to the literature through open access journals and scholarship repositories, and section VI describes one law school's programs to provide open access to its own scholarship. Section VII offers suggestions for law schools and law libraries willing to pursue the implications of the access principle in their institutions.

\section{THE FREE ACCESS TO LAW MOVEMENT}

\section{A. Montreal Declaration on Public Access to Law}

In October 2002, delegates to the fourth Law via Internet Conference in Montreal issued a Declaration on Public Access to Law stating that:

- Public legal information from all countries and international institutions is part of the common heritage of humanity. Maximizing access to this information promotes justice and the rule of law;

- Public legal information is digital common property and should be accessible to all on a non-profit basis and, where possible, free of charge;

- Independent non-profit organizations have the right to publish public legal information and the government bodies that create or control that information should provide access to it so that it can be published. ${ }^{17}$

The initial Montreal Declaration was issued by representatives of legal information institutes (LIIs) ${ }^{18}$ from eight areas of the world. It was

${ }^{17}$ See Declaration on Public Access to Law (Oct. 3, 2002), http://www.worldlii.org/worldlii/declaration/montreal_en.html.

${ }^{18}$ In a paper tracing the development of the free access to law movement, Greenleaf, Chung, and Mowbray define "legal information institute" as: a provider of legal information that is independent of government, 
amended at two later meetings of the LIIs, most significantly in 2003, when the title of the declaration was changed to call for "free," rather than for "public" access to law, and the qualification "where possible" was deleted from the original statement that public legal information "should be accessible to all on a non-profit basis and, where possible, free of charge."19

Today, more than five years after the Montreal Declaration was first promulgated, there are fourteen national and regional legal information institutes linked from the web site of the World Legal Information Institute (WorldLII). ${ }^{20}$ At this writing, the WorldLII site provides a search facility for databases located on the sites of other legal information institutes and its own databases. Currently, the site provides access to 877 databases of legal information from 123 countries. $^{21}$ Greenleaf, Chung and Mowbray point out that only a minority of legal jurisdictions world-wide provide comprehensive free electronic access to essential legal information through government web sites, or by providing the data to independent sites. ${ }^{22}$ There are also a few other non-governmental sites that provide extensive access to legal information without calling themselves legal information institutes and "hundreds of less comprehensive free Internet sources of caselaw, legislation and other essential legal information."23

and provides free access on a non-profit basis to multiple sources of essential legal information, including both legislation and caselaw (or alternative sources of jurisprudence).... They are therefore, in essence, aggregators of public legal information at a national or sometimes regional level.

Graham Greenleaf, Philip Chung \& Andrew Mowbray, Emerging Global Networks for Free Access to Law: WorldLII's Strategies 5 (March 22, 2007), http://ssrn.com/ abstract=975614.

${ }^{19}$ See Declaration on Free Access to Law (Oct. 3, 2002, as amended), http:/www.worldlii.org/worldlii/declaration/. The history and development of the movement for free access to law can be found on the web site of the World Legal Information Institute (WorldLII) at http://www.worldlii.org/ (last visited Feb. 18, 2008) and in Greenleaf, Chung \& Mowbray, supra note 18, 7-9. See also Daniel Poulin, “Open Access to Law in Developing Countries,” First Monday, Dec. 2004, http://firstmonday.org/issues/issue9_12/poulin/index.html.

${ }^{20}$ See WorldLII web site, supra note 19.

${ }^{21}$ http://www.worldlii.org/databases.html (last visited Feb. 18, 2008).

${ }^{22}$ Greenleaf, Chung \& Mowbray, supra note 18, at 6.

${ }^{23} \mathrm{Id}$. In the U.S., see, e.g., Altlaw, a project of programs at the Columbia Law School and the University of Colorado Law School, which provides free access to opinions of the U.S. Supreme Court and the federal courts of appeal. See http://www.altlaw.org/ (last visited Feb.18, 2008). 
The Declaration on Free Access to Law emphasizes access to "public legal information," which is defined in the declaration to be:

legal information produced by public bodies that have a duty to produce law and make it public. It includes primary sources of law, such as legislation, case law and treaties, as well as various secondary (interpretative) public sources, such as reports on preparatory work and law reform, and resulting from boards of inquiry. It also includes legal documents created as a result of public funding. ${ }^{24}$

\footnotetext{
${ }^{24}$ Declaration on Free Access to Law, supra note 19 (emphasis added). The
} distinction drawn between primary and secondary sources of law in the Declaration is probably more applicable to common law jurisdictions than to civil law jurisdictions. In common law countries such as the United States, legal scholarship is usually classified as "secondary" literature, and is distinguished from the "primary" sources of law issued by bodies with law- or rule-making authority: legislatures, courts, and administrative agencies. Secondary authority cannot bind a court, but can be cited to persuade the court of the soundness of an argument. For a discussion of the differences among sources of law in the U.S. written for international lawyers, see Jill J. Ramsfield, Culture to Culture: A Guide to U.S. Legal Writing 45-61 (2005).

In other legal systems, distinctions between primary and secondary sources of law are less clearly drawn. See Claire M. Germain, Germain's Transnational Law Research § 2.07 .3 (1991-) (The common law distinction between primary and secondary authority "does not exist in civil countries which give more respect to commentary on the law in books and articles.”) See also René David \& John E.C. Brierley, Major Legal Systems in the World Today: An Introduction to the Comparative Study of Law 148 (3d. ed. 1985) (noting that in Romano-Germanic legal systems the "relationship between legislation and doctrinal commentary ... is much more complex, much more delicate," and that "[l]egal scholarship is thus of fundamental importance because it creates in different countries the various working tools of jurists.”). On the role of scholars, see John Henry Merryman \& Rogelio Pérez-Perdomo, The Civil Law Tradition: An Introduction to the Legal Systems of Europe and Latin America 56-60 (3d ed. 2007) ("The teacher-scholar is the real protagonist of the civil law tradition. The civil law is a law of the professors." Id. at 56). See also Mary Ann Glendon, Michael W. Gordon \& Paolo G. Carozza, Comparative Legal Traditions in a Nutshell 89-94 (2d ed. 1999). On academic legal writing (la doctrine) in France, see Eva Steiner, French Legal Method 179-182 (2002). Thanks to Claire Germain for her help with these points.

The LII definition of legal information seems to follow the common law approach to classifying legal materials. A recent paper about the establishment of the Asian Legal Information Institute (AsianLII), however, notes that an Asia-wide legal information system will need to consider a full range of legal systems, and presumably other approaches to classifying legal materials. See Graham Greenleaf, Philip Chung \& Andrew Mowbray, "Challenges in Improving Access to Asian Laws: 
The Declaration states that independent, non-profit organizations have a right to publish public legal information, and that governments should provide them access to the information so that they can publish it. ${ }^{25}$ Greenleaf, Chung and Mowbray argue convincingly that access to legal information through LIIs and other non-governmental publishers is essential not only to fill gaps in access that long predate the Internet and the web, but "to ensure that free access is not second-rate access."26 Similarly, although John Willinsky does not write specifically about law or about access to legal research and scholarship, he, like those involved in the Free Access to Law Movement, emphasizes the need for alternative sources of access to public information. Willinsky also includes academic research within his sense of public information. ${ }^{27}$

It is appropriate for a movement to make legal information freely and openly available to all to focus first on improving access to legislation, case law, and treaties. The Montreal Declaration highlights those materials, which it calls "primary sources of law," and defines "secondary" sources in terms that limit their scope to public or publicly-funded documents. ${ }^{28}$ Greenleaf, Chung and Mowbray acknowledge that, while only a small number of journals are available in LII databases, law journals too can be considered "public legal information" and are an area of possible expansion for the LIIs. ${ }^{29}$ In describing legal information institutes as providers of "essential legal information,"30 they emphasize that:

We are not suggesting that the LIIs should only provide essential legal information. They are likely to be involved in the provision of other types of secondary material such as law journals. ... These sources require different considerations from 'essential' legal information, particularly because their

the Asian Legal Information Insitute (AsianLII),” 9 Aust. J. Asian L. 152, 155-157 (2007).

${ }^{25}$ Declaration on Free Access to Law, supra note 19.

${ }^{26}$ Greenleaf, Chung \& Mowbray, supra note 18, at 11 ("Governments may or may not publish the information themselves, but competition will help ensure that one or more versions are available for free access.”).

${ }^{27}$ Willinsky, supra note 1 , at 133 ("To move academic research more thoroughly into the public domain is to create a substantial alternative source of public information.”)

${ }^{28}$ Declaration on Free Access to Law, supra note 19.

${ }^{29}$ Greenleaf, Chung \& Mowbray, supra note 18, at 25.

${ }^{30}$ The phrase "essential legal information" is not used in the Montreal Declaration. 
publication is less likely to be pursuant to a duty to publish, or public subsidies to do so. ${ }^{31}$

As of this writing, about 45 LII law journal databases, mostly from the Australian Legal Information Institute (AustLII), are listed and linked on the WorldLII site. ${ }^{32}$ In addition, the WorldLII site's Catalog and Web search facilities link to and search over 350 journal web sites world-wide. ${ }^{33}$

\section{B. Other Open Access Initiatives}

The October 2002 Montreal Declaration was issued at a time when other groups were making well-publicized statements regarding the importance of open access to published scholarly and research literature in other disciplines. The Budapest Open Access Initiative (BOAI) ${ }^{34}$ was issued in February 2002 and the Berlin Declaration on Open Access to Knowledge in the Sciences and Humanities in October 2003. ${ }^{35}$ Unlike the Declaration on Free Access to Law, the Budapest and Berlin statements emphasize access to scholarly literature and research results--things published mainly in scholarly journals-especially in the sciences. The BOAI, for example, makes clear that it "only seeks open access for the scientific and scholarly research texts that

${ }^{31}$ Greenleaf, Chung \& Mowbray, supra note 18, at 5, n. 9.(emphasis added)

${ }^{32}$ http://www.worldlii.org/int/journals/ (last visited Feb. 18, 2008).

${ }^{33}$ http://www.worldlii.org/catalog/2303.html (last visited Feb. 18, 2008). For a description of these tools, as well as WorldLII's "Law on Google” search option, see Greenleaf, Chung \& Mowbray, supra note 18, at 38-41.

${ }^{34}$ Budapest Open Access Initiative (Feb. 14, 2002), http://www.soros.org/ openaccess/read.shtml.

${ }^{35}$ Berlin Declaration on Open Access to Knowledge in the Sciences and Humanities (October 22, 2003), http://oa.mpg.de/openaccess-berlin/berlindeclaration. html.

Issued at about the same time as the Budapest and Berlin documents, the June 2003 Bethesda Statement on Open Access Publishing focused on practical matters: "significant, concrete steps that all relevant parties--the organizations that foster and support scientific research, the scientists that generate the research results, the publishers who facilitate the peer-review and distribution of results of the research, and the scientists, librarians and others who depend on access to this knowledge--can take to promote the rapid and efficient transition to open access publishing.” Bethesda Statement on Open Access Publishing (Apr. 11, 2003, released June 20, 2003), http://www.earlham.edu/ peters/fos/bethesda.htm. 
authors give to publishers and readers without asking for any kind of royalty or payment." 36

Neither the Declaration on Free Access to Law, nor the other open access declarations, argue for a right of open access to information. ${ }^{37}$ Nor do they discuss the possible sources for a rights-based access argument in the Universal Declaration of Human Rights ("Everyone has the right freely to participate in the cultural life of the community, to enjoy the arts and to share in scientific advancement and its benefits"), ${ }^{38}$ in the International Covenant on Economic, Social and Cultural Rights ("The States Parties to the present Covenant recognize the right of everyone: . . . To enjoy the benefits of scientific progress and its applications”), ${ }^{39}$ or perhaps most explicitly in the International Covenant on Civil and Political Rights ("Everyone shall have the right to freedom of expression; this right shall include freedom to seek, receive and impart information and ideas of all kinds, regardless of frontiers, either orally, in writing or in print, in the form of art, or through any other

${ }^{36}$ Budapest Open Access Initiative: Frequently Asked Questions: Research Literature (last revised Jan. 31, 2008), http://www.earlham.edu/ peters/fos/boaifaq.htm\#literature.

${ }^{37}$ In contrast to the open access statements, the International Federation of Library Associations and Institutions (IFLA) Statement on Libraries and Intellectual Freedom includes a declaration "that human beings have a fundamental right to access to expressions of knowledge, creative thought and intellectual activity, and to express their views publicly.” International Federation of Library Associations and Institutions, Statement on Libraries and Intellectual Freedom (approved Mar. 25, 1999), http://www.ifla.org/faife/policy/iflastat/iflastat.htm.

However, like the other open access statements, IFLA's 2003 Statement on Open Access to Scholarly Literature and Research Documentation does not attempt to argue for a right of access to information. Nor does it refer back to the right of access declared in the IFLA Statement on Libraries and Intellectual Freedom. Instead, the IFLA open access statement "affirms that comprehensive open access to scholarly literature and research documentation is vital to the understanding of our world and to the identification of solutions to global challenges and particularly the reduction of information inequality.” International Federation of Library Associations and Institutions, Open Access to Scholarly Literature and Research Documentation (adopted Dec. 5, 2003), http://www.ifla.org/V/cdoc/open-access04.html.

${ }^{38}$ Universal Declaration of Human Rights Article 27 (1), G.A. Res. 217A, at 71, U.N. GAOR, 3d Sess., 1st plen. mtg., U.N. Doc. A/810 (Dec. 12, 1948), available at http://www.unhchr.ch/udhr/lang/eng.htm.

${ }^{39}$ International Covenant on Economic, Social and Cultural Rights Article 15, §1(a), Dec. 16, 1966, 993 U.N.T.S. 3; S. Exec. Doc. D, 95-2 (1978); 6 I.L.M. 360 (1967), available at http://www2.ohchr.org/english/law/cescr.htm. 
media of his choice." $)^{40}$ In The Access Principle, Willinsky suggests that the argument for a right of access to knowledge can be made on these grounds:

The right to know that is inherent in the access principle has a claim on our humanity that stands with other basic rights, whether to life, liberty, justice, or respect. More than that, access to knowledge is a human right that is closely associated with the ability to defend, as well as to advocate for, other rights. ${ }^{41}$

For Willinsky, the right to know involves not only "fair and equitable access to a public good." Under the access principle it also invokes "the responsibility of researchers and scholars to ensure that there are no unwarranted impediments to the widest possible circulation of the ideas and information with which they work." 42

Although they do not argue for a right of open access to information, the Declaration on Free Access to Law and the other open access declarations do include language regarding human knowledge and common cultural heritage that resonates with the Universal Declaration of Human Rights and the International Covenant on Economic, Social and Cultural Rights. ${ }^{43}$

\footnotetext{
${ }^{40}$ International Covenant on Civil and Political Rights Article 19.2., Dec. 16, 1966, 999 U.N.T.S. 171; S. Exec. Doc. E, 95-2 (1978); 6 I.L.M. 368 (1967), available at http://www2.ohchr.org/english/law/ccpr.htm. Access to scientific information is emphasized in the 1999 declaration of the World Conference on Science, sponsored by the United Nations Educational, Scientific and Cultural Organization (UNESCO) and the International Council for Science. See U.N.E.S.C.O., World Conference on Science, June 26-July 1, 1999, Declaration on Science and the Use of Scientific Knowledge, para. 4.42, U.N. Doc. 30 C/15, App. I (August 18, 1999), available at http://unesdoc.unesco.org/images/0011/001169/116994E.pdf ("Equality in access to science is not only a social and ethical requirement for human development, but also a necessity for realizing the full potential of scientific communities worldwide and for orienting scientific progress towards meeting the needs of humankind.”).

${ }^{41}$ Willinsky, supra note 1 , at 143 . Willinsky bases his position in Richard Pierre Claude's arguments for a "right of access to the advancement of science" and those of Jacques Derrida for a "right to philosophy." Id. at 143-154. See also Peter Johan Lor \& Johannes Britz, "Knowledge Production from an African Perspective: International Information Flows and Intellectual Property,” 37 Int'l. Info. \& Libr. Rev. 61, 67 (2005) (basing the argument for information rights on "the assumption that essential information is a basic resource in any society that needs to survive and develop.”).

${ }^{42}$ Willinsky, supra note 1 , at 146.

43 The Declaration on Free Access to Law places public legal information within "the common heritage of humanity," supra note 19; the Budapest Initiative states that
} 
Perhaps because of its emphasis on primary sources of law issued by "public bodies that have a duty to produce law and make it public," the Montreal Declaration comes closest to suggesting a rights-based justification for the subject of its concerns. ${ }^{44}$

\section{THE VALUE OF ACCESS TO LEGAL SCHOLARSHIP: LAW JOURNALS AND EMERGING ALTERNATIVES}

Commentary on the law is written by law professors, judges, lawyers, law students, and others to discuss, explain, or analyze the law (as it stands or as it should be), and to point researchers toward pertinent authorities in the sources issued by legislatures, courts, and other bodies with law-making power, the sources that the Montreal Declaration calls "public legal information." 45 This literature serves to support and to influence the professional work of judges, lawyers, and legal scholars and to explain the law to the public. The relative importance of specific forms of legal scholarship (treatises, journal artivles, commentaries, etc.) varies between the Romano-Germanic, or civil law, tradition and that of the common law; ${ }^{46}$ among countries classified within one or the other of those systems; ${ }^{47}$ and over time. $^{48}$

The focus in this article is on the scholarship (and other material) typically published in law journals. Particularly in the United States, papers

open access to the literature of scientific research will "lay the foundation for uniting humanity in a common intellectual conversation and quest for knowledge," supra note 34; and the Berlin Declaration defines "open access as a comprehensive source of human knowledge and cultural heritage that has been approved by the scientific community," supra note 35.

${ }^{44}$ The Declaration states that public legal information "should be accessible to all on a non-profit basis and free of charge" (emphasis added), and does declare the right of "Independent non-profit organisations ... to publish public legal information." Declaration on Free Access to Law, supra note 19.

${ }^{45}$ See supra text accompanying note 24.

${ }^{46}$ See supra note 24.

${ }^{47}$ See David \& Brierley, supra note 24, at 148 ("What troubles the French jurist when he studies German law is the difference in form, rather than of substantive law, between the legal works of French and German jurists. The latter, as well as the Swiss, prefer a form of annotated codes (Kommentaire) .... The preferred instrument of the French jurist is the more systematic treatise (traite) or manual ....”).

${ }^{48}$ See A.W. B. Simpson, "The Rise and Fall of the Legal Treatise: Legal Principles and the Forms of Legal Literature," 48 U. Chi. L. Rev. 632 (1981) (discussing the changing roles of legal treatises in common law jurisdictions, focusing on England and the U.S.). 
published in specialized legal journals have been the predominant form of legal scholarship since the late nineteenth century after Christopher C.

Langdell introduced modern approaches to university legal education at the Harvard Law School. ${ }^{49}$ The student-edited Harvard Law Review began publication in $1887,,^{50}$ and similar student-edited journals and reviews were soon established at other U.S. law schools. ${ }^{51}$ Although frequently criticized (most often by law professors who had themselves served as student-journal editors while in law school), ${ }^{52}$ student-edited journals published at law

${ }^{49}$ There is a large literature on Langdell and on legal education at Harvard. A useful critical review of much of the Langdell literature is Bruce A. Kimball, "The Langdell Problem: Historicizing the Century of Historiography, 1906-2000s," 22 Law \& Hist. Rev. 277 (2004). Kimball also provides a detailed portrait of legal education at Harvard during the early years of Langdell's deanship in Bruce A. Kimball, "Students' Choices and Experience During the Transition to Competitive Academic Achievement at Harvard Law School, 1876-1882,” 55 J. Legal Educ.163 (2005).

${ }^{50}$ This was not the first student-edited law journal. Frederick C. Hicks, the foremost bibliographer of U.S. law, considered an 1822 publication of a law school in Needham, Virginia to be "the first law school publication with a periodical title." See Frederick C. Hicks, Materials and Methods of Legal Research 206 (3d rev. ed. 1942). For descriptions of efforts to establish journals at the Albany and Columbia law schools prior to the start of the Harvard Law Review, see Michael I. Swygert \& Jon W. Bruce, "The Historical Origins, Founding, and Early Development of StudentEdited Law Reviews,” 36 Hastings L.J. 739, 763-769 (1985). The University of Pennsylvania Law Review dates its origins (under other titles) to 1852, but was not edited by students until 1896. See Edwin J. Greenlee, "The University of Pennsylvania Law Review: 150 Years of History,” 150 U. Penn. L. Rev. 1875, 1880 (2002). The earliest U.S. law journal is considered to be the American Law Journal and Miscellaneous Repertory, which was published irregularly from 1808 to 1817 and included reports of decisions, plus some commentary. See Hicks, supra at 197-198.

It may be worth noting that in its first issue, the student editors of the Harvard Law Review stated that their journal was "not intended to enter into competition with established law journals, which are managed by lawyers of experience." "Notes," 1 Harv. L. Rev. 35, 35 (1887). Rather, their primary objective was "to set forth the work done in the school with which we are connected, to furnish news of interest to those who have studied law in Cambridge, and to give, if possible, to all who are interested in the subject of legal education, some idea of what is done under the Harvard system of instruction.” Id. Thanks to Bob Berring for this reference.

${ }^{51}$ See Swygert \& Bruce, supra note 49, at 779-787, for a history of early studentedited law journals at other U.S. law schools.

${ }^{52}$ There is a large critical literature on the institution of the student-edited law journal in the U.S., extending back at least to the often-cited Fred Rodell, "Goodbye to Law Reviews," 23 Va. L. Rev. 38 (1936). Some of this literature is referenced and critiqued in Leah M. Christensen \& Julie A. Oseid, "Navigating the Law Review Article Selection Process: An Empirical Study of Those With All the Power - Student 
schools remain the dominant forum for publication of legal scholarship in the United States. $^{53}$ Some law school journals are faculty-edited and peerreviewed, some are issued by professional and scholarly societies, some are published by commercial or university presses. ${ }^{54}$

The law school-published, student-edited journal is an uncommon form for publication of legal scholarship outside the U.S., ${ }^{55}$ but faculty- and practitioner-edited journals are significant sources for legal information and commentary on the law in all countries. Law journals became important vehicles for legal scholarship in England and in South Africa (the other countries whose journals are examined later in this article) at about the same time as in the U.S., ${ }^{56}$ but in those countries almost all law journals are published by commercial or university presses rather than directly by law

Editors,” 59 S.C. L. Rev. 175 (2008). For a pointed recent critique of law reviews and legal scholarship, see Michael J. Madison, “The Idea of the Law Review: Scholarship, Prestige and Open Access,” 10 Lewis \& Clark L. Rev. 901 (2006).

${ }^{53}$ One count suggests that 597 of 889 law journals published in the U.S. are student-edited. See Law Journals: Submissions and Ranking, http://lawlib.wlu.edu/LJ/index.aspx (last visited Feb. 18, 2008). The site, maintained at the Washington \& Lee Law School, excludes "[m]ost bar journals, magazines, and newsletters."

Thomson Scientific calculates impact factors for 100 law journals, published at law schools and by commercial or university presses. A journal's impact is based on later citations to articles published in the journal. For 2006, 17 of the 20 journals with the highest impact factors were published at law schools and edited by law students. The data are available at: Journal Citation Reports, available through http://www. isiwebofknowledge.com/ (last visited Feb. 18, 2008) (password required).

${ }^{54}$ See, e.g., Journal of Legal Studies (1972-), a peer-reviewed journal edited by members of the University of Chicago Law School faculty; Law and History Review (1983-), published by the University of Illinois Press for the American Society for Legal History; Law \& Social Inquiry (1988-), published by Blackwell Publishing for the American Bar Foundation.

${ }^{55}$ But see, e.g., Bucerius Law Journal (2007-), http://www.law-journal.de/ About_us. 171.0.html (last visited Feb. 18, 2008), a student-edited journal published at the Bucerius Law School in Hamburg, Germany. The relative ease of publishing journals on the web may make student-edited journals more common. See those cited infra note 79.

${ }^{56}$ See Simpson, supra note 48, at 662 ("Although legal periodicals had been in existence for some time, they did not provide an outlet for scholarly writing [in England] until the Law Quarterly Review was inaugurated in 1885 . . . .”). According to Hicks, the first English law journal was the Lawyers' Magazine, which was published from 1761-1762. Hicks, supra note 50, at 197. In South Africa, the South African Law Journal began publication in 1884 under the title: Cape Law Journal. 
schools. ${ }^{57}$ In civil law countries, "legal periodicals, which are run by professors rather than students, play a much more important role ... than in common law countries in bringing new legislation and court opinions to the attention of the profession." ${ }^{\text {"S }}$ Lawyers in civil law jurisdictions rely on legal journals both as sources for the full texts of decisions and for annotations discussing their significance. "Such legal periodicals are an indispensible tool of legal research." 59 These comments emphasize the value of law journals for practicing lawyers in civil law countries. Their value to practicing attorneys in common law jurisdictions is less certain, and challenges to their usefulness are long-standing topics for legal commentators, at least in the U.S. ${ }^{60}$ In March 2007, several federal judges' comments on data showing a decrease in federal court citations to law review articles in their opinions ${ }^{61}$ were found newsworthy enough to be reported in the New York Times. ${ }^{62}$ Do declining

${ }^{57}$ A recent ranking of U.K. law journals indicates that the twenty most highly ranked journals are all published by commercial presses. For the list of journals, see Kevin Campbell, Alan Goodacre \& Gavin Little, "Ranking of United Kingdom Law Journals: An Analysis of the Research Assessment Exercise 2001 Submissions and Results,” 33 Journal of Law and Society 335, 356 (2006) (Table 6: Ranking of Law Journals by the Implied Rating Metric). For an historical perspective, see George S. Grossman, Legal Research: Historical Foundations of the Electronic Age 287-288 (1994). Similarly, all the South African journals examined in this article are issued by or in association with commercial presses.

${ }^{58}$ Glendon, Gorman, \& Carozza, supra note 24, at 91.

${ }^{59}$ Id. at 92. The discussions of doctrinal writings in the Parker School's standard guides to foreign legal materials each include representative periodicals for topics covered. See Charles Szladits, Guide to Foreign Legal Materials: French, German, Swiss 477-493 (1959); Charles Szladits \& Claire M. Germain, Guide to Foreign Legal Materials: French 108-142(2d rev. ed. 1985); Timothy Kearley \& Wolfram Fischer, Charles Szladits' Guide to Foreign Legal Materials: German 135-140 (2d rev. ed. 1990); Paul Graulich, Paulette Guillitte, Jan F. Glastra van Loon \&L. E. Van Holk, Guide to Foreign Legal Materials: Belgium, Luxembourg, Netherlands 67-84, 197255 (1968); Angelo Grisoli, Guide to Foreign Legal Materials: Italian 118-230 (1965). For a discussion of notes d' arrêts in French legal scholarship, see Steiner, supra note 24 , at 183-185.

${ }^{60}$ See, e.g., Harry T. Edwards, "The Role of Legal Education in Shaping the Profession,” 38 J. Legal Educ. 285, 291 (1988) (“Law professors seem more and more often content to talk only to each other--or perhaps to a few colleagues in other academic disciplines--rather than deal with the problems facing the profession.”)

61 Trends in Federal Judicial Citations and Law Review Articles (Mar. 8, 2007), http:/graphics8.nytimes.com/packages/pdf/national/20070319_federal_citations.pdf.

${ }^{62}$ Adam Liptak, "When Rendering Decisions, Judges Are Finding Law Reviews Irrelevant,” N.Y. Times, Mar. 19, 2007, at A8. The press coverage of the Cardozo program tended to highlight the comments that the judges made about law reviews 
citations to law review articles mean that legal scholarship is less relevant to practicing lawyers and courts than it might have been in the past?

Responding to the judges' comments, Stephen Vladeck argues that, if lack of judicial citations to legal scholarship really is a problem, "the solution is not to change the content of our scholarship. For any number of reasons, we should continue to have faith that, if we are doing our job correctly, our scholarship is still relevant." ${ }^{\text {"3 }}$ Instead, legal scholars should find ways to make their work accessible not only to judges, but to officials in administrative agencies and practitioners who are in better positions to make use of it. ${ }^{64}$ Vladeck suggests that the appropriate vehicles toward this end might be found in the emerging "short forms" of legal scholarship, such as Conntemplations, the web-based companion to the Connecticut Law Review, in which he published his short article. Like other emerging law school

(e.g., "Judges use them like drunks use lampposts ... more for support than illumination.”). Id. (quoting Judge Robert D. Sack).

${ }^{63}$ Stephen I. Vladeck "The Law Reviews vs. the Courts: Two Thoughts From the Ivory Tower" 8 (May 1, 2007), http://www.conntemplations.org/index.php?m=05\&y= 07\&entry=entry070501000000, available in PDF at http://www.conntemplations.org/pdf/vladeck.pdf (emphasis in original). Page references here and in the following footnotes are to the PDF version.

${ }^{64}$ Vladeck suggests that the decreasing citation of law review articles in judicial opinions is explained not by the quality or relevance of contemporary legal scholarship, but by changes in the work that twenty-first century judges are asked to do. Because "judges in general-and appellate judges in particular--are held to increasingly narrow resolution of the substantive legal issues before them ... these jurists are encountering fewer opportunities today to consider the novel legal theories or interpretations of doctrine for which legal scholarship has traditionally been valuable." Id. at 3. 
companions, ${ }^{65}$ Conntemplations encourages commentary and responses to the pieces it publishes. ${ }^{6}$

The growing interest of legal scholars and practicing attorneys alike in blogs, ${ }^{67}$ wikis, ${ }^{68}$ and law review companions, as well as in purely electronic short-form law journals, ${ }^{69}$ has prompted speculation about the potential of these new forms to improve communications between academic lawyers and the bar, ${ }^{70}$ and to alter the channels of scholarly discourse in law. ${ }^{71}$ Like

${ }^{65}$ See, e.g., The Yale Law Journal Pocket Part, http://yalelawjournal.org/ (last visited Feb. 18, 2008); PENNumbra, http://www.pennumbra.com/, (last visited Feb. 18, 2008). See generally Ken Strutin, "Guide to Short Form Open Access Legal Publications” (July 27, 2007), http://www.llrx.com/features/shortformjournals.htm.

Readers of legal journal articles from countries other than the U.S. are aware that legal scholarship can be written in much "shorter form" than the lengthy and heavilyreferenced articles typical of U.S. authors. See, e.g., Richard A. Danner, "Applying the Access Principle in Law: The Responsibilities of the Legal Scholar, 35 Int'l. J. Legal Info. 355 (2008). The lead articles from the current issues of the U.S. law journals examined below average 64 pages in length; those from the U.K., 22 pages; those from South Africa, 23 pages. See Shane Tintle, Note, "Citing the Elite: The Burden of Authorial Anxiety,” 57 Duke L.J. 477 (2007) (arguing that legal authors use excessive citations as a means to "manage the impression" of their works).

${ }^{66}$ As of this writing, Vladeck's own piece, posted on May 1, 2007, has attracted no comments or responses on the Conntemplations web site.

${ }^{67}$ See, e.g., Brian Leiter's Legal Philosophy Blog, http://leiterlegalphilosophy. typepad.com/ (last visited Feb. 18, 2008); The Volokh Conspiracy, http://volokh.com/ (last visited Feb. 18, 2008). See generally Margaret A. Schilt, "The Future of Legal Scholarship” Legal Times, July 9, 2007, at 27; Some Evidence for the Assimilation of Blogs into the Structure of Legal Literature, http://lawprofessors.typepad.com/ law_librarian_blog/2008/02/the-assimilatio.html (Feb. 5, 2008).

${ }^{68}$ A well-known example is the collaborative wiki used by Lawrence Lessig in writing his book Code: Version 2.0 in 2006. The wiki can be found at: http://www. socialtext.net/codev2/index.cgi (last visited Feb. 18, 2008). A discussion of legal wikis and a representative list is at Robert J. Ambrogi, "Legal Wikis Are Bound to Wow You," Law Tech. News, May 7, 2007, http://www.law.com/jsp/ihc/PubArticleIHC. jsp?id=1178541412778.

${ }^{69}$ See, e.g., Duke Law and Technology Review, http://www.law.duke.edu/journals/ dltr/ (last visited Feb. 18, 2008), which publishes short "issue briefs." DLTR also publishes iBlawg, a blog intended to facilitate discussion of its articles. See http://www.law.duke.edu/journals/dltr/iblawg/ (last visited Feb. 18, 2008).

${ }^{70}$ See, e.g., "Blogs and Scholars: The Impact of Legal Blogging on the Bench and Bar," Nat'l. L.J., Oct. 8, 2007, at 22 (discussion among legal educators, judges and practitioners). 
Michael Carroll, ${ }^{72}$ Joseph Scott Miller has pointed out some of the benefits of open access for legal scholars: extending the reach of one's scholarship, increasing the speed at which works are distributed, and creating new impact measures such as download counts. ${ }^{73}$ But Miller also suggests the possible aids to collaboration if works are accessible in forms employing tagging and other tools of social networking software that allow authors and readers both to read and to comment. "Open access scholarship, by virtue of its openness on the web, can spark the creation of a new social layer of metadata that connect and comment on that scholarship." ${ }^{\text {74 }}$ As James Boyle has written:

The genius of the web is that it is an open network. Anyone can link to any part of this page, or that article, and anyone else can link to that link. That web of interconnections, crosscitations and linkages is then captured by search engines. We gain not only the knowledge in the content, but the knowledge supplied by those who read the content, who make connections the original author could not. ${ }^{75}$

The need for informed commentary about the law should not in doubt, whether it is published in traditional print journal formats, in allelectronic journals (enhanced perhaps by the emerging communication tools of the web), or posted in new shorter forms using those tools. The continued publication (and introduction) of law journals in legal systems of all types suggests the ongoing importance of the traditional journal article and the value to scholars and others of having access to the scholarship and other

${ }^{71}$ See Brian Leiter, "Why Blogs are Bad for Legal Scholarship,” 116 Yale L.J. Pocket Part 53 (2006), http://yalelawjournal.org/2006/09/20/leiter.html, available on the cite in PDF format. Page references are to the PDF version. Although a prominent blogger himself, see supra note 67, Leiter argues that "blogs have been bad for legal scholarship, leading to increased visibility for mediocre scholars and half-baked ideas and to a dumbing down of standards and judgments.” Id. at 57. In law, unlike other disciplines, scholarly discourse is mediated by student journal editors and (for the public) by journalists, making it easier for legal blogs to facilitate "the repeated and systematic broadcast of non-expert opinions," which then gain credibility through repetition. Id. at 53 .

${ }^{72}$ See Carroll, supra note 3, at 755-757.

${ }^{73}$ Joseph Scott Miller, "Foreword: Why Open Access to Scholarship Matters," 10 Lewis \& Clark L. Rev. 733, 735-738 (2006).

${ }^{74}$ Id. at 737.

${ }^{75}$ James Boyle, “The Irony of a Web Without Science.” Financial Times, Sept. 4, 2007, at11 (discussing the impacts of the costs of peer-reviewed scientific journals). 
content of the journals. Is this literature accessible to all who will benefit from it? ${ }^{76}$

In other disciplines, much of the original impetus for open access to research results and scholarship stemmed from the increasingly higher barriers to access posed by the rising costs of already expensive scientific, technological, and medical journals. ${ }^{77}$ Law journals generally are less expensive than journals in other disciplines, ${ }^{78}$ and cost considerations are perhaps less significant as a barrier to access. Are law journals already accessible enough to those who will benefit from their contents? Are open access platforms necessary to enable legal scholars to fulfill their responsibilities under the access principle?

\section{ACCESSIBILITY OF THE LAW JOURNAL LITERATURE}

Judged by their covers, which often retain the simple type faces and designs of their first volumes, many twenty-first century law journals seem not to have moved far from their print origins in the late nineteenth century. Although there are new law journals in all-electronic formats, ${ }^{79}$ new print

${ }^{76}$ Some portion of the output of legal scholars may be so specific to the law of a particular jurisdiction that it will be of limited interest to researchers outside the jurisdiction. Yet, substantial amounts of the literature may be of broader use. See supra text accompanying notes 133-134 for geographic spread of downloads of papers in the Duke Law School Faculty Scholarship Repository. See also Greenleaf, Chung \& Mowbray, supra note 24, at 155-157.

${ }^{77}$ For comparative journal subscription prices in the sciences and other disciplines, see Lee C. Van Orsdel \& Kathleen Born, "Periodicals Price Survey 2007: Serial Wars,” Libr. J., Apr. 15, 2007, at 43. Van Orsdel and Born's figures indicate that in 2007, the average subscription cost was US\$3,429 for 209 journal titles in chemistry, US $\$ 2,865.00$ for 214 titles in physics, and US\$1,676 for 213 titles in biology. Id. at 44 .

${ }^{78}$ The most recent edition of the American Association of Law Libraries Price Index for Legal Publications, 4d, http://www.aallnet.org/members/price_index2006.asp (last visited Feb. 18, 2008)(password required), lists a 2006 annual cost of US\$285.86 for 167 “commercial” legal periodicals (“association journals, bar journals, and joint ventures with academic institutions") and an average cost of US\$39.43 for 147 "academic" periodicals, published at law schools or in other academic settings. Van Orsdel and Born found the average subscription cost for 74 U.S. law journals to be US\$247.00. Van Orsdel \& Born, supra note 77, at 44.

${ }^{79}$ Washington \& Lee's Law Journals: Submissions and Ranking web site, supra note 53 (last visited Feb. 18, 2008) lists 94 online only law journals, some of which are web companions to print journals. See E.g., Potchefstroom Electronic Law Journal (1998-), 
journals continue to be introduced and to be collected, bound, and preserved by law libraries. ${ }^{80}$ How accessible electronically are the articles published in traditional law journals? To get an idea, I looked at ten highly ranked law journals in three countries: the United States, ${ }^{81}$ the United Kingdom, ${ }^{82}$ and the Republic of South Africa. ${ }^{83}$

\section{A. Database Access}

Most, if not nearly all, print law journals are widely available in commercial databases. The major international legal databases, LexisNexis and Westlaw each include extensive runs of U.S. law journals, with some international coverage. Hein Online provides access to a nearly comprehensive collection of U.S. law journals, with full retrospective collections for many, and recent issues for some, as well as an extensive list

http://www.puk.ac.za/opencms/export/PUK/html/fakulteite/regte/per/index. html (last visited Feb. 18, 2008); Freilaw, http://www.freilaw.de/ (last visited Feb. 18, 2008);

Unbound: Harvard Journal of the Legal Left (2005-), http://www.legalleft.org/ (last visited Feb. 18, 2008).

${ }^{80}$ E.g., Akron Intellectual Property Journal (2007-); Legisprudence: International Journal for the Study of Legislation (2007-).

${ }^{81}$ The U.S. journals are those with the highest 2006 impact factors as calculated by Thomson Scientific in its Journal Citation Reports. Alphabetically, they are: American Journal of International Law, California Law Review, Columbia Law Review, Harvard Law Review, Michigan Law Review, New York University Law Review, Stanford Law Review, Texas Law Review, Virginia Law Review, Yale Law Journal. See Journal Citation Reports, supra note 53.

${ }^{82}$ The U.K. journals are those ranked 1-10 by Campbell, Goodacre \& Little, supra note 57. Alphabetically, they are: Cambridge Law Journal, Law Quarterly Review, Common Market Law Review, Oxford Journal of Legal Studies, International and Comparative Law Quarterly, Journal of Law and Society, Lloyd's Maritime and Commercial Law Quarterly, Modern Law Review, Civil Justice Quarterly, Industrial Law Review.

83 The South African journals are those listed in Amanda Barratt \& Pamela Snyman, Researching South African Law (Mar. 2005), http://www.nyulawglobal.org/globalex/South_Africa.htm, as updated in November 2007 by Amanda Barratt. Alphabetically, they are: Comparative and International Law Journal of Southern Africa, Industrial Law Journal, South African Journal of Criminal Justice, South African Journal on Human Rights, South African Law Journal, SA Mercantile Law Journal, Stellenbosch Law Review, SA Publiekreg / SA Public Law, Tydskrif vir die Suid-Afrikaanse Reg / Journal of South African Law, Tydskrif vir Hedendaagse Romeins-Hollandse Reg / Journal of Contemporary Roman Dutch Law. Annuals and yearbooks listed by Barratt \& Snyman are not included. Email from Amanda Barratt to Richard Danner (Nov. 6, 2007, 09:27 EST) (on file with author). 
of international and non-U.S. law journals. ${ }^{84}$ JSTOR's collection of journals in law includes full runs of major U.S. journals and a few journals from outside the U.S. ${ }^{85}$ In the U.K., where law journals are usually published by commercial publishers, current issues, some back volumes, and individual articles from new issues are frequently available for purchase on publisher web sites. ${ }^{86}$ In South Africa, the articles in most major law journals are generally accessible electronically through Sabinet Online to subscribers, although not on a per article basis for nonsubscribers. ${ }^{87}$ Table 1 shows the accessibility through selected databases of substantial content from the 30 journals I examined, and suggests generally wider availability of journals published in the U.S. than for those from the U.K. and South Africa in those databases

Table 1. Accessibility of Law Journal Content through Selected Databases

\begin{tabular}{|l|c|c|c|c|c|}
\hline Country/Database & Westlaw & $\begin{array}{c}\text { Lexis/ } \\
\text { Nexis }\end{array}$ & Hein Online & JSTOR & Sabinet \\
\hline United States (10) & 10 & 10 & 10 & 8 & 0 \\
\hline United Kingdom (10) & 5 & 5 & 7 & 3 & 0 \\
\hline South Africa (10) & 0 & 0 & 6 & 0 & 7 \\
\hline
\end{tabular}

Although at least some of the content of important journals in law is available in commercial databases, those works are accessible only to researchers affiliated with institutions that have paid for licensed access to the databases, or in some cases on a pay-per-article basis from the publisher of the journal. A number of programs provide low cost or free access to journals in selected subjects to researchers in developing countries, but they typically

${ }^{84}$ See http://www.heinonline.org/home/content/Browse.html (last visited Feb. 18, 2008).

${ }^{85}$ See http://www.jstor.org/about/asIV.list.html (last visited Feb. 18, 2008). JSTOR does not include either current issues or usually the most recent completed volumes for many of the journals it covers.

${ }^{86}$ See, e.g., the law journals listed on the Cambridge University Press web site at http://journals.cambridge.org/action/bySubjectArea\#subject20 (last visited Feb. 18, 2008).

${ }^{87}$ See Sabinet Law Collection, http://www.journals.co.za/collections/collect_law.html (last visited Feb. 18, 2008). Sabinet provides access to 42 South African legal journals via pre-paid subscriptions. 
focus on the sciences and include access to few law journals. ${ }^{88}$ Somewhat greater access to law journals is provided through the activities of the International Network for the Availability of Scientific Publications (INASP) ${ }^{89}$ and Electronic Information for Libraries (eIFL.net). ${ }^{90}$

\section{B. Access through Journal Web Sites}

Lund University's Directory of Open Access Journals (DOAJ) suggests that few law journals are freely available on the web. Of 3203

${ }^{88}$ HINARI, the World Health Organization's Health InterNetwork Access to Research Initiative, provides free or very low cost online access to journals in biomedical and related social sciences, but only 20 of HINARI's present 3,750 journals deal with law. See http://extranet.who.int/hinari/en/browse_journal_ subject.php?subj= law (last visited Feb. 18, 2008). AGORA (Access to Global Online Research in Agriculture), a program of the Food and Agriculture Organization of the UN provides access to resources in the fields of food, agriculture, environmental science and related social sciences, but does not include a subject category for law and includes only one or two law journals under the heading Economics/Social Sciences in its current list of over 1,100 journals. See http://www.aginternetwork.org/agorasearch/search/subject Category.do?subject CategorySelected=econ\&subjectCategoryLabel=Economics/Social\%20Science (last visited Feb. 18, 2008). OARE (Online Access to Research in the Environment), a consortium coordinated by the United Nations Environment Programme (UNEP), provides free access to about 1,300 environmental science journals, only five of which focus on environmental law. See http://oare.oaresciences. org/content/en/browse_journal_subject.php?subj=env_st_pol (last visited Dec. 16, 2007).

See generally Willinsky, supra note 1, at 101-103. There is some sense that noncommercial (professional and society) publishers are less aware of these programs than large commercial publishers. See E-journals: Developing Country Access Survey, 2002 at 6 (2003), http://www.inasp.info/file/360/e-journals-developingcountry-access-survey-2002.html.

${ }^{89} \mathrm{http} / / /$ www.inasp.info/ (last visited Feb. 18, 2008). INASP works with about 50 international publishers to facilitate access to their publications in over 40 developing countries. Publishers with significant law content include: Blackwell Publishing, Cambridge University Press, Oxford Journals, Project Muse, and the University of Chicago Press. See Publishers Working with INASP, http://www.inasp.info/file/186/ publishers-working-with-inasp.html (last visited Feb. 18, 2008).

${ }^{90}$ http://www.eifl.net/cps/sections/home/ (last visited Feb. 18, 2008). eIFL.net negotiates electronic journal subscriptions on a multi-country consortial basis, working with nearly 50 member countries and nearly 30 publishers and aggregators including Cambridge University Press, Oxford University Press, and Project Muse. See http://www.eifl.net/cps/sections/services/negotiations (last visited Feb. 18, 2008). 
journals listed on DOAJ, only 56 are listed under law. ${ }^{91}$ Of those, 22 are published in the U.S. None of the 30 law journals studied here are found on the DOAJ site.

The number of open access journals listed for law is surprisingly low, even for the U.S., where nearly all law journals are published at law schools for the purposes of disseminating scholarship and providing educational experiences for student editors. Although there are usually no expectations of profit for these journals, law schools and student editors contemplating open access to their journals may be concerned about losing print subscribers. ${ }^{92}$ In addition, because they enjoy unlimited (and apparently cost-free) access to law journals and other information through Westlaw, LexisNexis, Hein Online, and other databases, it might be hard for law students and faculty to appreciate the impacts of access costs on researchers outside the U.S. legal education environment. Law students also hold their appointments as journal editors for only short periods before graduating and moving on into legal careers, and have few incentives to consider long-term issues in scholarly communication. Perhaps for those reasons, only a few journals have signed on to the principles of the Science Commons Open Access Law Program (OALP) ${ }^{93}$ a project to promote open access in law journal publishing. Since OALP's Open Access Law Journal Principles were promulgated in 2005, fewer than 40 law journals (nearly all from the U.S.) have either adopted the principles or indicated that they are operating under policies consistent with them. ${ }^{94}$ Only two of the 30 journals examined for this article are listed as adopters.

${ }^{91}$ http://www.doaj.org/doaj?func=home (last visited Feb. 22, 2008). According to its web site, the DOAJ "aims to be comprehensive and cover all open access scientific and scholarly journals that use a quality control system to guarantee the content.” http://www.doaj.org/doaj?func=loadTempl\&templ=about (last visited Feb. 18, 2008).

${ }^{92}$ In addition to their income from print subscribers, law school journals also generate some income by licensing their content to the commercial data bases; the licenses are non-exclusive, but the income might be threatened if the content were made freely available as well as through the databases. For the circulation totals of some U.S. law journals, see Paul Caron \& Rafael Gely, "What Law Schools Can Learn From Billy Beane and the Oakland Athletics,” 82 Tex. L. Rev. 1483, 1535 n. 296 (2004) (book review). Subscriber counts for Duke Law School's print journals are in Table 2, infra at p. 386.

93 http://sciencecommons.org/projects/publishing/oalawjournal (last visited Feb. 18, 2008).

${ }^{94}$ http://sciencecommons.org/projects/publishing/oalawjournals/ (last visited Feb. 18, 2008). 
Although only a few law journals are listed in the Directory of Open Access Journals or as signatories to the Open Access Law Project, many others have significant web presences. ${ }^{95}$ At least for U.S. journals, the DOAJ and OALP lists understate the number of journals that make the texts of at least some articles available in PDF format on their own web sites. To get a suggestion of the accessibility of articles available on law journal sites, I looked at the lead article ${ }^{96}$ in the most recent issue print issue received at the Duke Law Library for each of the U.S., U.K., and South African journals examined for this article.

Eight of the 10 U.S. journals I examined in January 2008 had posted free PDF versions of the articles in their current issues on their web site, and usually had archives of articles from recent volumes available on the site. One journal was several issues behind in mounting issues when I checked; the other apparently does not provide access to articles through its site. Free access to current articles was far less common for the U.K. and South African journals, which are issued by commercial or university publishers. The lead article from one U.K. journal was freely accessible on the journal web site (perhaps as a promotion, because the journal had recently switched publishers). Selected articles from one South African journal (including the current lead article at the time of my study) are regularly available without charge on the journal's site. Non-subscribers can purchase individual articles on the sites of 6 of the 10 U.K. journals. In sum, for the 30 journals examined, 10 lead articles from current issues were available without charge on the journal web sites and another 6 were available to non-subscribers for individual purchase on the sites.

How does a researcher find freely available articles posted on law journal web sites without knowing that a specific journal posts articles on its site? My own Google searches (by title) provided links to 12 of the 16 articles available, free or for-fee, on the journal sites; Google Scholar searches linked to 8 of those 12 . Searches on OAIster, ${ }^{97}$ a harvester of publicly

\footnotetext{
${ }^{95}$ See, e.g., the links to law journal sites in the WorldLII journals catalog, http://www.worldlii.org/catalog/54588.html (last visited Feb. 18, 2008), and those linked from Washington \& Lee's Law Journals Submissions and Ranking page, supra note 53.

${ }^{96}$ I considered the lead article to be the first full article printed in the issue. I did not include memorials, notes, editorials, or short pieces in cases and comments sections, all of which appeared on the first pages of one or more of the journals.

${ }^{97}$ http://www.oaister.org/ (last visited Feb. 18, 2008).
} 
accessible web resources, provided links sites to 3 of the lead articles in the current issues of the journals. ${ }^{98}$

\section{REPOSITORIES OF LEGAL SCHOLARSHIP}

\section{A. Gold Roads and Green Roads}

In the literature of the open access movement, the idea of replacing the traditional profit-driven journal publishing system with freely available open access journals is often referred to as "the gold road" to open access. An alternative route, sometimes called "the green road," relies less on replacing the existing scholarly publishing structure with open access journals than on encouraging the authors of scholarly works to self-post (or self-archive ${ }^{99}$ ) versions of their works on open sites, while continuing to publish them formally in the journals of their discipline. ${ }^{100}$ Herbert Van de Sompel has noted that in the electronic environment one of the main functions of any scholarly communication system-helping participants in the system to be aware of new claims and findings-can be accomplished in the electronic environment not only by publishing new research in journals, but by author postings of papers in digital repositories of scholarship. Electronic postings fulfill "the awareness function by making manuscripts freely available via the network, by allowing search engines to index content, and by sending alerts to

${ }^{98}$ The Google, Google Scholar, and Oaister searches also found links to versions of some articles that had been posted by their authors to one of the primary repositories for scholarship in law: the Legal Scholarship Network (part of the Social Science Research Network (SSRN) and the bepress Legal Repository (a product of Berkeley Electronic Press). Google searches linked to repository versions of 11 of the 30 lead articles, while OAIster linked to three. Repositories are discussed in greater detail infra, Section V. SSRN and bepress are both based in the U.S. but aim to disseminate scholarship to world-wide audiences. Papers in law that are posted to SSRN and bepress are generally, but not always, freely available on the sites.

${ }^{99}$ Although the term "self-archiving" is frequently used by proponents of this approach to describe authors' posting of their works in open access sites, it is important to note that "archiving" is defined to include access to and usage of the works, but not long-term preservation. See, e.g., Stevan Harnad, Against Conflating OA Self-Archiving With Preservation-Archiving, http://users.ecs.soton.ac.uk/harnad/Hypermail/ Amsci/5500.html (July 11, 2006).

${ }^{100}$ See generally Jean-Claude Guédon, "The "Green" and "Gold” Roads to Open Access: The Case for Mixing and Matching,” 30 Serials Rev. 315 (2004). Without those labels, the two strategies are also set forth in the Budapest Open Access Initiative, supra note 34. 
interested scholars." ${ }^{\text {"101 }}$ Stevan Harnard of the University of Southampton has been an early and persistent advocate of author self-archiving, at least for prepublication (or pre-print) versions of scholarly papers. ${ }^{102}$

The best-known early application of author self-archiving is the archive for researchers in high-energy physics established in 1991 at the US. National Library in Los Alamos, New Mexico. ${ }^{103}$ Now operated at Cornell University, arXiv.org currently hosts author-submitted papers in physics, mathematics, computer science, quantitative biology, and statistics. By focusing on research in selected subject areas, arXiv.org provides an example of a disciplinary repository, open to papers from researchers anywhere on the subject areas covered. ${ }^{104}$

Since 2002, open access advocates and others have touted institutional repositories, which are defined not in terms of subject matter, but as: "digital collections capturing and preserving the intellectual output of a single or multi-university community."105 Institutional repositories are

${ }^{101}$ Herbert Van de Sompel, et al, "Rethinking Scholarly Communication: Building the System that Scholars Deserve,” D-Lib Mag., Sept. 2004, http://www.dlib.org/dlib/ september04/vandesompel/09vandesompel.html. Van de Sompel identifies the functions of scholarly communication as: registration, certification, awareness, archiving, and rewarding, basing his classification on Hans E. Roosendaal \& Peter A. Th. M. Geurts, Forces and Functions in Scientific Communication: An Analysis of Their Interplay (1997), available at http://www.physik.uni-oldenburg.de/conferences/ crisp97/roosendaal.html. Roosendahl and Geurts define the main functions of scientific communication as registration, awareness, certification and archiving. Compare with Christine L. Borgman, Scholarship in the Digital Age: Information, Infrastructure, and the Internet 65-68 (2007) (identifying the functions of scholarly communication as legitimization, dissemination, and (taken together) access, preservation, and curation).

102 The full texts of many of Harnad's numerous publications on author-archiving and open access can be found at: http://users.ecs.soton.ac.uk/harnad/intpub.html (last visited Feb. 18, 2008). See, e.g., Stevan Harnad, India, Open Access, the Law of Karma and the Golden Rule (2007), http://eprints.ecs.soton.ac.uk/14432/.

103 http://arxiv.org/ (last visited Feb. 18, 2008).

104 The uses of repositories and other means for sharing documents and other information vary by discipline. See Borgman, supra note 101, at 180-226, for a comparative discussion of disciplinary practices for disseminating information in the sciences, the social sciences, and the humanities. Borgman does not discuss law.

${ }^{105}$ Raym Crow, The Case for Institutional Repositories: A SPARC Position Paper 4 (2002). For a current picture of institutional repositories in the U.S., see Soo Young Rieh et al "Census of Institutional Repositories in the U.S.: A Comparison 
intended to serve the dual goals of reforming scholarly communication and showcasing the scholarship produced at the institution. ${ }^{106}$ They are typically used not only to archive scholarship in its traditional forms, but also to hold other information (course materials, data sets, etc.) created at the institution. ${ }^{107}$ The best-known platform for large multi-disciplinary repositories designed to house a variety of digital objects is DSpace, which was developed at the Massachusetts Institute of Technology. ${ }^{108}$ Smaller scale institutional repositories of the sort more likely to be established at the school or departmental levels in universities are commonly supported by other platforms. The most well-known is probably EPrints, developed at the University of Southampton and now in use at 243 institutions world-wide. ${ }^{109}$

Across Institutions at Different Stages of IR Development,” D-Lib Mag., Nov./Dec. 2007, http://www.dlib.org/dlib/november07/rieh/11rieh.html.

${ }^{106}$ See Crow, supra note 105, at 6. See also Robert Mitchell, Harvard to Collect, Disseminate Scholarly Articles for Faculty, Feb. 13, 2008, http://www.news.harvard.edu/gazette/2008/02.14/99-fasvote.html (describing a decision by the Harvard Faculty of Arts and Sciences to make each faculty member's scholarly articles available in a free open-access repository maintained by the university).

${ }^{107}$ See Clifford A. Lynch, "Institutional Repositories: Essential Infrastructure for Scholarship in the Digital Age,” ARL Bimonthly Report (Feb. 2003), http://www.arl.org/resources/pubs/br/br226/br226ir.shtml.

${ }^{108} \mathrm{http}: / /$ www.dspace.org/ (last visited Feb. 18, 2008). For background, see MacKenzie Smith et al., "DSpace: An Open Source Dynamic Digital Repository,” DLib Mag., Jan. 2003, http://www.dlib.org/dlib/january03/smith/01smith.html. Large institutional repositories can also be hosted by outside services such as bepress's Digital Commons. See http://www.bepress.com/ir/ (last visited Feb. 18, 2007). bepress Digital Commons customers include universities in Australia, Japan, New Zealand, and the United Kingdom, as well as colleges and universities in the U.S., and some U.S. law schools. See http://www.bepress.com/ir/customers.html (last visited Feb. 18, 2008)

${ }^{109}$ http://www.eprints.org/ (last visited Feb. 18, 2008). Like DSpace, EPrints is an open source software product. School- or departmental-level repositories can also be established using outside hosts. Selected Works, http://works.bepress.com/ (last visited Feb. 18, 2008), hosts customized pages for smaller institutions, such as law schools, that wish to showcase and provide full-text access to the works of their faculties without maintaining their own on-site repository. See, e.g., Selected Works @ Chicago-Kent College of Law, http://works.bepress.com/kentlaw/ (last visited Feb. 18, 2008). See generally Mark Sutherland \& Peta Hopkins, Open Source or Off-theShelf: Establishing an Institutional Repository for a Small Institution (2006), http://epublications.bond.edu.au/library_pubs/11/. 


\section{B. Disciplinary Repositories in Law}

Legal scholars in the U.S. and in other countries have taken to the green road approach for disseminating their works through their posting of papers in disciplinary repositories. The most prominent is the Social Science Research Network, which provides repository services for a number of disciplines, including law through the Legal Scholarship Network. ${ }^{110}$ The bepress Legal Repository, part of the Berkeley Electronic Press (bepress) offers a similar platform and services. ${ }^{111}$

Both legal repositories encourage individual scholars to post their works, without charging for the service, ${ }^{112}$ and allow anyone to view and download papers posted on their sites. Papers posted on the sites can be found through searches on each site and through Google and other general search engines. ${ }^{113}$ SSRN is also linked from the WorldLII web site and is listed as one of WorldLII's 45 or so law journals databases. ${ }^{114}$ Some bepress papers are also accessible through OAIster. In addition, each repository provides a number of fee-based services, such as subscriptions to email announcements of new papers in selected subjects or written by faculty members at designated law schools. ${ }^{115}$ SSRN makes free subscriptions to its

${ }^{110}$ http://www.ssrn.com/ (last visited Feb. 18, 2008). In her discussion of variations in disciplinary practices regarding distribution and sharing of documents, Borgman notes that few of the social sciences have the resources to invest in large scale disciplinary repositories. See Borgman, supra note 101, at 207

${ }^{111}$ http://law.bepress.com/repository/ (last visited Feb. 18, 2008).

${ }^{112}$ At present, however, neither repository provides the sorts of opportunities for collaboration and comment provided by law review companions and other short form legal publications. See Beth Simone Noveck, "Wikipedia and the Future of Legal Education,” 57 J. Legal Educ. 3, 3-4 (2007) (describing how SSRN's policy against including links to wikis or other outside sources in the abstracts for posted papers changed the author's plans for using her draft article as the basis for readers to share experiences about using wikis in law teaching).

${ }^{113}$ Although it did not occur in the searches for these articles, Google searches for law journal articles sometimes turn up links to SSRN that lead to abstracts for the article on the SSRN site, but to the full text. Occasionally, the abstract pages list download counts for the article, suggesting that the full text had been posted to SSRN, but was withdrawn from the repository when the paper was accepted for publication in the journal.

${ }^{114}$ See supra, note 32.

${ }^{115}$ SSRN hosts working paper series in law for about 20 law schools or other legal institutions outside the U.S. 
email announcements (called "abstracting journals") available to users in developing countries. ${ }^{116}$

Author-postings of papers to open access repositories, in both preprint and final versions, are increasingly common in all disciplines (sometimes with time delays or embargoes ${ }^{117}$ ) for a number of reasons: opposition to the rising costs of journal subscriptions, pressure from authors and open access advocates, and sometimes because of the requirements of funding agencies. ${ }^{118}$ These factors operate to a lesser extent in law, where author postings of new works in SSRN and bepress are driven primarily by their authors' wishes to make their new works widely known (and frequently downloaded) as quickly as possible, and in law school's desires to showcase their faculties' scholarly efforts. The repositories respond to these interests by tallying the download counts for posted papers. For each of its papers, SSRN posts public totals for the number of times the abstract for a paper has been viewed and the paper itself has been downloaded; ${ }^{119}$ bepress reports numbers of downloads directly to the author.

${ }^{116}$ See SSRN's Objective and Commitments to Users (Aug. 2007), http://www. ssrn.com/index.cfm.

${ }^{117}$ See Adam L. Penenberg, "Time to Kill the Embargo" (Dec. 23, 2004), http://www.wired.com/culture/lifestyle/news/2004/12/66112.

${ }^{118}$ On December 17, 2007, the Scientific Council of the European Research

Council (ERC) released an open access policy requiring that:

all peer-reviewed publications from ERC-funded research projects be deposited on publication into an appropriate research repository where available, such as PubMed Central, ArXiv or an institutional repository, and subsequently made Open Access within 6 months of publication.

ERC Scientific Council Guidelines for Open Access (Dec. 17, 2007), available at http://erc.europa.eu/pdf/ScC_Guidelines_Open_Access_revised_Dec07_FINAL.pdf.

In January, 2008, the United States enacted legislation stating requiring that: all investigators funded by the [National Institutes of Health ] submit or have submitted for them to the National Library of Medicine's PubMed Central an electronic version of their final, peer-reviewed manuscripts upon acceptance for publication to be made publicly available no later than 12 months after the official date of publication."

Consolidated Appropriations Act of 2008, Pub. L. No.110-161, § 218, 121 Stat 1844, 2187

For new developments on matters of open access publishing, see Open Access News: News from the Open Access Movement, http://www.earlham.edu/ peters/ fos/fosblog.html (last visited Feb. 18, 2008).

${ }^{119}$ SSRN also publicizes lists of its most frequently downloaded papers. See Top 10 Papers for Legal Scholarship Network, http://papers.ssrn.com/sol3/topten/ topTenResults.cfm?groupingtype=2\&groupingId=201 (last visited Feb. 18, 2008). 
In the United States, the popularity of the SSRN and bepress legal repositories suggests that the journals to which legal scholars submit their works for formal publication (frequently after they have been posted and publicized on one or both repositories), are comfortable with a culture that both allows and encourages authors to assume some of the responsibility for disseminating their works. It is difficult to know how many journals actually allow broad self-posting in their author publication agreements. The model author agreement promoted by the Association of American Law Schools allows authors to post works accepted for publication "on web sites under the author's control,"120 a condition that might not cover postings on SSRN and bepress, but would presumably cover postings on authors' personal home pages or in repositories hosted by their own institution. The principles of the Science Commons Open Access Law Program do allow posting on third party sites, but as noted above relatively few journals have so far signed on. ${ }^{121}$

Researchers can find papers posted to SSRN and bepress through Google and other general search engines and are usually freely available once located. ${ }^{122}$ But, if we take the responsibilities of the access principle seriously, is it enough to rely on authors posting their own their works to the disciplinary repositories provided by SSRN and bepress? My look at the current issues of top U.S., U.K., and South African law journals found that versions of only 11 of the 30 lead articles in those journals were posted to either SSRN or bepress (or to both), and that two of those articles were available only on a fee basis. What more can be done to help the creators of legal scholarship meet their responsibilities under the access principle? In particular, what can law schools and law libraries do to ensure that legal scholarship is freely and openly available? Is there a role to be played by institutional repositories hosted at individual law schools or established through collaborative effort? Some sense of the possibilities might be found in looking at the experiences of one law school that has pursued an open

${ }^{120}$ Association of American Law Schools, Model Author/Journal Agreement para. 2.b.iii (May 18, 1998) (Deans Memorandum 98-24), http://www.aals.org/deansmemos/ 98-24.html .

${ }^{121}$ See supra text accompanying notes 93-94.

122 Although both SSRN and bepress are “.com” sites, SSRN's stated objective "is to provide worldwide distribution of research to authors and their readers and to facilitate communication among them at the lowest possible cost." SSRN's Objective and Commitments to Users, supra note 116; bepress's mission statement says that its "portfolio of products and services ... reduces the costs of, and barriers to, access." Berkeley Electronic Press, Mission Statement, http://www.bepress.com/aboutbepress.html (last visited Feb. 18, 2008). 
access agenda for its journals and to expose the works of its faculty to larger audiences.

\section{DUKE LAW SCHOOL}

The Duke University School of Law in Durham, North Carolina, is a privately funded institution with 630 students enrolled in its three year juris doctor program, an additional 85-100 students each year in its international LLM program, several SJD students, and a full-time faculty of 52. Duke publishes six traditional student-edited print law journals ${ }^{123}$ and two electronic journals. ${ }^{124}$ Articles published in the print journals are available through LexisNexis, Westlaw, Hein Online, and other databases, as well as on the Duke Law web site.

\section{A. Web Journals}

In 1998, Duke began posting new articles from its six print journals on the law school web site. ${ }^{125}$ The faculty task force that developed the project considered the possible effects on print subscriptions of making available free electronic versions of the journals, but concluded that the benefits of providing greater exposure for the Duke journals to scholars in other disciplines and to international readers would outweigh any potential reductions in income from print subscriptions or in royalties from the versions available through the legal databases. New issues of each journal are mounted on the Duke web site in HTML and PDF formats upon or before their publication in print. On the site, back issues extend to 1996 or 1997, with links to Hein Online for older volumes. All Duke Law journals are listed in the Directory of Open Access Journals and are signatories to the principles of the Science Commons Open Access Law Program. ${ }^{126}$

\footnotetext{
123 They are: the Duke Law Journal (1951-); Law \& Contemporary Problems (1933-); the Alaska Law Review (1984-); the Duke Journal of Comparative \& International Law (1991-); the Duke Environmental Law \& Policy Forum (1991-); and the Duke Journal of Gender Law \& Policy (1994-).

124 They are the Duke Law \& Technology Review (2001-), supra note 69, and the Duke Constitutional and Public Law Journal (2006-), http://www.law.duke.edu/ journals/djclpp/ (last visited Feb. 18, 2008) which publishes an annual print volume in addition to its electronic postings.

${ }^{125}$ http://www.law.duke.edu/scholarship/journals (last visited Feb. 18, 2008)

${ }^{126}$ See supra text accompanying notes 91-94.
} 
Table 2. Duke Law Journals: Paid Subscribers 1996-2007

\begin{tabular}{|l|l|l|l|l|l|l|}
\hline & 1996 & 1998 & 2001 & 2003 & 2005 & 2007 \\
\hline L\&CP & 1656 & 1745 & 1627 & 1691 & 1716 & 1713 \\
\hline DLJ & 930 & 998 & 879 & 892 & 895 & 912 \\
\hline ALR $^{127}$ & 343 (est.) & 389 (est.) & 347 & 346 (est.) & 349 & 345 \\
\hline DJCIL & 309 & 333 & 329 & 355 & 359 & 363 \\
\hline DELPF & 165 & 187 & 194 & 205 & 212 & 212 \\
\hline DJGLP & 125 & 161 & 170 & 193 & 186 & 193 \\
\hline
\end{tabular}

After ten years of providing and promoting free access, the impacts on print subscriptions to the journals have been minimal. Table 2 shows that subscribers to the law school's interdisciplinary quarterly, Law and Contemporary Problems, have increased since the journal has been available on the web site, while subscribers to the Duke Law Journal have decreased slightly. Most notably, perhaps, are the totals for the school's three subject specific journals. Those journals, which concentrate on international and comparative law, environmental law, and gender law, continue to have small numbers of subscribers, but each has shown significant increases in its subscriber base since the journals were made available on the web site. In addition, royalty income received from databases that provide access to articles published in the Duke journals has remained constant.

\section{B. Faculty Scholarship Repository}

In addition to making the articles in its student-edited journals openly accessible, Duke is also committed to maximizing access to works written by the Duke Law faculty, whether or not they are published in a Duke journal. The law school makes new faculty works available through SSRN via two working paper series: the Duke Law School Legal Studies Research Paper Series and the Duke Law School Science, Technology \& Innovation Paper Series ${ }^{128}$; and through bepress via the Duke Law School Working Papers

${ }^{127}$ Totals for the Alaska Law Review exclude copies purchased by the Alaska Bar Association for distribution to its members.

${ }^{128}$ See Legal Scholarship Network Research Paper Series, http://www.ssrn.com/ lsn/index.html (last visited Feb. 18, 2008). 
Series. ${ }^{129}$ Most members of the faculty provide their new papers upon completion to the law school publications office for posting to SSRN and bepress without prompting; others do so in response to regular reminders about the repositories.

Since December 2005, Duke Law has maintained its own faculty scholarship repository hosted on a local server using EPrints software. ${ }^{130} \mathrm{~A}$ joint project of the law library and the law school's information technology staff, the faculty scholarship repository aims to include comprehensive holdings of the final versions of all works by current Duke faculty members, and over time to extend coverage retrospectively to cover works by everyone who has taught at Duke. The repository holds over 1400 papers and is searchable on the Duke Law web site, as well as through Google and other general web search engines. Because the repository complies with the standards and protocols of the Open Access Initiative, its holdings are also searchable through OAIster and other harvesters of open access repositories, as well as through Google and other search engines. ${ }^{131}$

Table 3 compiles data for the 10 papers that were most downloaded from the Duke repository in $2007{ }^{132}$ The data suggest both that the repository

${ }^{129}$ http://lsr.nellco.org/duke/fs/ (last visited Feb. 18, 2008).

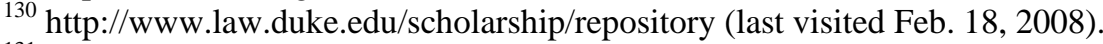

${ }^{131}$ A search for "law" in the Registry of Open Access Repositories (ROAR), http://roar.eprints.org/index.php (last visited Feb. 18, 2008), turns up three active registered legal repositories in addition to that at Duke. Two run EPrints software; one uses DSpace. Two of the three are at law schools in the United States (the University of Georgia Law School, http://digitalcommons.law.uga.edu/ (last visited Feb. 18, 2008); the University of Maryland School of Law), http://digitalcommons.law.umaryland.edu/ (last visited Feb. 18, 2008). The other is in Africa at the University of Cape Town (UCT) Law Faculty. The UCT LawSpace repository "holds a selection of LL.M. Minor Dissertations in full text. Dissertations (including Ph.D. and Masters Dissertations), publications and conference papers will be added regularly.” http:// lawspace.law.uct.ac.za/ (last visited Feb. 18, 2008).

132 The raw download figures should be treated cautiously. Our analysis of the statistical program used for the Duke repository suggests that it does a reasonable job at eliminating counts of spider-generated downloads, but any of a number of other automated processes could inflate the totals. Because of the difficulties in ensuring accurate counts, I present them here primarily to suggest trends and for showing the breakdown between U.S. and non-U.S. downloads. Because it is difficult to ensure accuracy, I have not provided the names of authors or titles of the papers. One source, with an interest in ensuring accurate download figures suggests that "By the end of 2007 ..., without filtering, one out of every two logged downloads from academic sites will be made by machine or mistake.” See bepress Download Totals: 
is a popular source for works of Duke Law authors and that the papers are being downloaded by substantial audiences around the world. For the 10 papers listed, fully 25 percent of the total downloads recorded came from outside the U.S. The five papers with the fewest percentages of non-U.S. downloads (8.7-19.7 percent) each deal with particular topics in U.S. law. ${ }^{133}$ For the five papers on less specifically U.S. topics, 44.5 percent of the downloads came from outside the U.S., suggesting that for many topics, the audience for legal scholarship is both large and widespread. ${ }^{134}$

Table 3. Duke Law School Repository: Most-Downloaded Papers-2007

\begin{tabular}{|l|l|l|l|l|l|}
\hline Author & Date & Total & Non-US & \% Non-US & Countries \\
\hline A(I) & 2006 & 1,782 & 172 & 9.6 & 45 \\
\hline A(II) & 2005 & 1,493 & 130 & 8.7 & 39 \\
\hline B & 2005 & 1,188 & 523 & 44.0 & 68 \\
\hline C & 2006 & 1,132 & 122 & 10.8 & 37 \\
\hline D & 2006 & 989 & 214 & 21.6 & 47 \\
\hline E & 2006 & 860 & 629 & 73.1 & 68 \\
\hline F & 1997 & 697 & 137 & 19.7 & 15 \\
\hline G & 2006 & 694 & 245 & 35.3 & 53 \\
\hline H & 1998 & 687 & 83 & 12.1 & 16 \\
\hline I & 2006 & 676 & 296 & 43.8 & 28 \\
\hline Totals & -- & 10,198 & 2,551 & 25.0 (ave.) & 41.6 (ave.) \\
\hline
\end{tabular}

Not surprisingly, 6 of the 10 most-downloaded papers in 2007 are also on the "all-time" top 10 list of papers downloaded since the repository

Numbers You Can Count On, http://www.bepress.com/download_counts.html (last visited Feb. 18, 2008).

${ }^{133}$ Two papers deal with medical malpractice in individual U.S. states; the others with uses of presidential signing statements, the "filibuster" (a parliamentary technique used in the U.S. Senate), and measures for ranking U.S. law schools.

${ }^{134}$ These papers deal with individual rights before the European commission, appearance regulation in the workplace, transaction cost economics, the history of drinking water, and the competitive structure of the accounting industry. 
went public in December 2005. It is also not surprising that 8 of the 10 were published in 2005 or 2006. However, it is worth noting as well that the other two most-downloaded papers in 2007 were originally published in 1997 and 1998. Of the top 20 most-downloaded papers in 2007, six were published in 2002 or earlier, suggesting an application in legal scholarship of the "long tail" phenomenon: the idea that older products (in this case pieces of scholarship) that appear to be in low demand will be used if they are made accessible, inexpensive, and findable, and can make up a significant share of their market. ${ }^{135}$

\section{CONCLUSIONS: IMPLEMENTING THE ACCESS PRINCIPLE}

As the Duke Law School example suggests, the possibilities for successfully promoting greater open access to legal scholarship are enhanced in the U.S. by the unique circumstances under which legal scholarship is published. The predominant publishing model, which relies on student-edited, institutionally-published journals, largely removes the interests of commercial publishers from the list of possible obstacles to open posting of papers in institutional and disciplinary repositories, or to publishing them in open access journals. Legal scholars in the U.S. feel free to post their work in the SSRN and bepress repositories, whether or not the journals that will eventually publish their articles are openly accessible or explicitly permit author postings. Infrastructure, bandwidth, and other technological issues are of little concern to the creators of legal scholarship, the institutions that publish and disseminate scholarship, or those seeking to access and use it. In other parts of the world, Law journals are usually published by commercial or society publishers with financial interests in limiting open access to the works they publish. And, in much of the rest of the world, limited bandwidth and infrastructure concerns create significant obstacles for all participants in the scholarly communications system (creators, disseminators, and users) in law, as in other disciplines. ${ }^{136}$

${ }^{135}$ The use of the phrase "long tail" to describe this phenomenon is usually attributed to Chris Anderson, “The Long Tail,” Wired Mag. (Oct. 2004), http://www. wired.com/wired/archive/12.10/tail.html.

${ }^{136}$ For a generally optimistic view of worldwide developments in access to information and communications technologies see World Information Society Report 2007: Beyond WSIS (2007). For information on efforts to improve bandwidth capacities for academic institutions in Africa, see The Bandwidth Consortium: Opening the Power of the Internet to African Universities, http://foundationpartnership.org/pubs/press/ bandwidth.php (last visited Feb. 18, 2008); IFC Invests in Landmark Project to Improve Telecommunications Access for 250 Million in Africa, Aug 2, 2007, http://www.ifc. 
World-wide, the prospects for improved access to legal scholarship (as well as to scholarship in other fields) are affected by the long-standing and present obstacles to free flow of information and knowledge between the developed countries of the North and the countries of the South. There is a substantial literature on this subject, much of which focuses on Africa. It is notable in this literature that the explosive development of information and communications technologies in recent decades and their expansion to the South are often cited not only as means for resolving problems of information flow, but also for widening the existing information gaps between researchers in the North and in the South, and for making it harder for researchers and scholars in developing countries to participate fully in scholarly discourse. ${ }^{137}$ Technological improvements have made possible international programs to make electronic versions of scholarly journals from Europe and the U.S. available free or at discounted rates to scholars in developing countries, ${ }^{138}$ but they have done less to make the scholarship of the South more visible outside the countries or regions where it is produced. As put by Subbiah Arunachalam, "research conducted in developing countries lacks visibility. Nobody notices it. Nobody quotes it. It gets buried in an obscure corner of the world output of literature."139 Pippa Smart has pointed out that the imbalance in what is published and accessible to researchers in the sciences

org/ifcext/media.nsf/content/SelectedPressRelease?OpenDocument\&UNID=2C0F34 E12F88C6548525732B006D403B. But see Michael Wines, "Toiling in the Dark: Africa's Power Crisis, N.Y. Times, July 22, 2007, at A10; Ron Nixon, “Africa Offline: Waiting for the Web," N.Y. Times, July 29, 2007, at BU.1; Calestous Juma, Give African Universities Free Internet Access (Oct. 11 2007), http://www.bdafrica.com/index.php? option=com_content\&task=view\&id=3563\&Itemid=5848. See generally Ezra Ondari-Okemwa, "Scholarly Publishing in Sub-Saharan Africa in the TwentyFirst Century: Challenges and Opportunities,” First Monday, Oct. 2007, http://www.uic.edu/htbin/ cgiwrap/bin/ojs/index.php/fm/article/view/1966/1842; Y.Z. Ya'u, “The New Imperialism \& Africa in the Global Electronic Village,” 99 Rev. Afr. Pol. Econ. 11, 16-17 (2004).

${ }^{137}$ See, e.g., Subbiah Arunachalam, "Information for Research in Developing Countries-Information Technology, a Friend or Foe?,” 35 Int'l. Info. \& Libr. Rev. 133, 135-137 (2003); Paul Tiyambe Zeleza, "Manufacturing and Consuming Knowledge: African Libraries and Publishing,” 6 Development in Practice 293, 296 (1996) ("basic infrastructural development is essential, and . . . in themselves the advanced technologies offer no magic solution to the challenges of information dissemination and scholarly communication facing Africa.”). See generally Ya'u, supra note 137.

${ }^{138}$ See supra text accompanying notes 88-90.

${ }^{139}$ Arunachalam, supra note 137, at 137. See also Lor and Britz, supra note 41, at 71-72. 
between North and South results in duplication of research, waste of resources, and biased interpretations of findings, ${ }^{140}$ and that poor dissemination and indexing of African research outside the African continent compounds the problem of low investment in local research: "the results of research are not made visible and potentially lose value-giving a lower return on investment for research institutes, and less rationale to invest in future research." ${ }^{\text {"141 }}$

Others have pointed out the threats that improved electronic access to international journals pose to local publishers. Diana Rosenberg asks "whether the 'flooding' of local markets with free or low-cost information from international sources might wipe out local publishers," noting that locally published journals in Africa are often "the natural channels for the publication of research relevant and valuable to the country concerned but not necessarily of interest to the main clients of research world-wide.”142

Suggestions for improving the visibility of scholarship produced in the South often call for better indexing of local journals and greater electronic access to the texts they publish, the kinds of services have developed over the last decade through African Journals Online (AJOL), a database of indigenous African publications that now indexes and abstracts nearly 300 journals. ${ }^{143}$ AJOL also provides access to the full-texts of many articles through fee-based document delivery services or links to the web sites of the journals themselves. Presently, AJOL lists only one law journal, Revue Burkinabè de droit, which may help explain why initiatives such as the Southern African

${ }^{140}$ Pippa Smart, "Increasing the Visibility of Published Research: African Journals Online,"Africa Today, Winter 2005, at 39, 42. For a discussion of the obstacles faced by authors from the South wishing to contribute to international journals in the sciences, see Johannes J. Britz \& Peter J. Lor, "A Moral Refection on the Information Flow from South to North: An African Perspective,” 53 Libri 160, 163 (2003). See also Ondari-Okemwa, supra note 136.

${ }^{141}$ Smart, supra note 140 , at 43.

${ }^{142}$ Diana Rosenberg, "African Journals Online: Improving Awareness and Access,” 15 Learned Publishing 51, 55 (2002). See also Britz \& Lor, supra note 41,at 164 ("Local journals play an essential role in the ecology of scientific communication. They publish material which, while not necessarily of interest in the developed North, may be of direct relevance and utility to the country of origin and its neighbors.”).

${ }^{143}$ See generally Smart, supra note 140, at 44-49; Rosenberg, supra note 142, at 52-55. Smart and Rosenberg were affiliated with INASP, the original sponsor of the AJOL project, at the time their papers were written. 
Legal Information Institute (SAFLII) include better access to secondary legal materials among their goals. ${ }^{144}$

The literature about improving information flow between North and South includes less about the potential uses of open access repositories to increase the visibility of research and scholarship than about improving journal publishing and indexing systems to achieve those ends. A 2002 article by Leslie Chan and Barbara Kirsop points out that repositories and other archiving initiatives provide opportunities for researchers in developing countries:

to contribute to the global knowledge base by archiving their own research literature, thereby reducing the south to north knowledge gap and professional isolation ... [and employing] an increasingly available means to distribute local research in a way that is highly visible and without the difficulties that are sometimes met in publishing in journals (e.g. biased discrimination between submissions generated in the north and south). ${ }^{145}$

In their article, Chan and Kirsop cite the significant world-wide usage of the high-energy physics site, arXiv.org, ${ }^{146}$ to show the benefits of disciplinary repositories in providing opportunities to participate to researchers from "research institutions that would otherwise be excluded from the front line of science for economic and sociological reasons." 147 A rich collection of information about recent repository developments in southern Africa can be found in the presentations of speakers at a November 2007 conference in Gabarone, Botswana, sponsored by the Southern African Regional Universities Association. ${ }^{148}$ Several of the presentations emphasized the improved visibility that repositories provide by noting the wide geographic spread of downloads of papers on the sites they discussed. ${ }^{149}$

\footnotetext{
${ }^{144}$ See About SAFLII, http://www.saflii.org/ (last visited Feb. 18, 2008).

${ }^{145}$ Leslie Chan \& Barbara Kirsop, “Open Archiving Opportunities for Developing Countries: Towards Equitable Distribution of Global Knowledge,” Ariadne ( Dec. 2002), http://www.ariadne.ac.uk/issue30/oai-chan/. See also Arunachalam, supra note 137, at 140-142; Lor \& Britz, supra note 41, at 72.

${ }^{146}$ See supra text accompanying note 103.

${ }^{147}$ Chan \& Kirsop, supra note 145.

${ }^{148}$ Open Access Leadership Summit, http://www.sarua.org:8180/web/guest/ OAsummit2007 (last visited Feb. 18, 2008).

${ }^{149}$ See Allison Fullard, AHERO: Harvesting for Access (Nov. 20, 2008), http://www.sarua.org/SARUA\%200A\%20Summit\%202007_AFullard.pdf (describing the development and programs of African Higher Education Research
} 
Writers on issues of access to scholarship in Africa and other parts of the developing world do not comment directly on legal scholarship or on issues of information flow for legal literature. Although legal journals are generally less costly than scientific, technology, and medical journals, many other circumstances regarding scholarship in law are similar to those of other disciplines, at least those in the social sciences. The responsibility to make their work widely accessible is at least as applicable to legal scholars as to scholars and researchers in other disciplines. But those who create legal scholarship are not the only participants in the system of scholarly communications for law. What can law schools, law librarians, technologists working in legal institutions, and the editors of law journals do to assist legal scholars in meeting the responsibilities of the access principle? In light of what we know about how legal scholarship is created, published and distributed throughout the world, what strategies will be most effective in improving access to legal commentary and ensuring the free flow of published scholarship between North and South?

Duke Law School's open access initiatives have been successful in improving access to scholarship published at Duke Law and to the works of the Duke faculty, and have made those works more visible to readers outside the U.S., to scholars in other disciplines, and to policy-makers in government and elsewhere. Sine 1998, free and open web access to Duke's journals has improved the visibility of articles published in the law school's smaller, specialized journals by making them readily accessible through standard search engines. In addition, open access has had generally beneficial effects on subscriptions to print versions of the school's journals while not diminishing income from the commercial databases that provide access to their content. In its third year, the Duke Law Faculty Scholarship Repository seems to be generating substantial traffic from both domestic and international readers, and creating greater visibility for the scholarship of the faculty, for older works as well as those more recently posted. Although many faculty articles are available in commercial databases, as well as in the

Online, the "1st OA disciplinary repository in Africa"); Hussein Suleman, Institutional Repositories: Why They are Important for African Research ( Nov. 21, 2008), http://www.sarua.org/SARUA\%20OA\%20Summit\%202007_\%20SUL-

EMAN.pdf; Susan Veldsman, Africa: Setting up Institutional Repositories (Nov. 21, 2008), http://www.sarua.org/SARUA\%200A\%20Summit\%202007_S\%20-

Veldsman.pdf (describing eIFL.net's repository programs, which have led to development of 96 institutional repositories in 20 developing countries, including 13 in Africa). 
SSRN and bepress working paper series, they are heavily-used from the repository site as well.

Duke Law's projects have also afforded opportunities for law librarians and information technologists to collaborate successfully with other law school offices and interested members of the faculty. Through their joint efforts, the school has established mechanisms to ensure that completed new works are posted to SSRN and bepress, and are also posted to the faculty repository after they are published. The student editors of Duke's journals proudly post their commitment to open access on the journals' web page. ${ }^{150}$ Duke Law's ongoing commitment to these activities has assisted its faculty in making their works widely, openly, and freely available, and in meeting the responsibilities encompassed in the access principle. The experience suggests the following actions that legal scholars and the institutions supporting them can take to create broader access to their scholarship:

- Legal scholars should insist that the journals which accept their works be openly accessible or at least allow authors to post their accepted works in institutional or disciplinary open access repositories.

- Librarians and others at institutions that support the work of legal scholars should actively assist scholars in locating open access journals and encourage them to publish in accessible venues.

- Legal scholars should post their works to disciplinary repositories such as SSRN and bepress, and negotiate agreements with publishers that will allow them to post versions of their works in local or in disciplinary repositories.

- Scholars, librarians, and others should encourage SSRN and bepress to develop common standards and policies to ensure long term open access to their holdings. ${ }^{151}$

- Legal scholars, librarians, and others should work together locally to ensure that journals affiliated with their institutions post their contents electronically in compliance with open access standards and that the content is picked up in search engines and open access harvesters.

- Legal scholars, librarians, and others should urge all journals affiliated with their institutions to post their policies regarding open

${ }^{150}$ See Duke Law Journals, http://www.law.duke.edu/scholarship/journals (last visited Feb. 18, 2008).

${ }^{151}$ See Gene Koo, Harvard's Open Publishing Policy and the Outlook for Law Schools, http://lsi.typepad.com/lsi/2008/02/harvards-open-p.html (Feb. 19, 2008). 
access and author postings of accepted articles, whether or not the journal operates under open access principles. ${ }^{152}$

- Librarians, scholars, journal editors, and others should raise institutional consciousness about open access publishing alternatives and support establishing registered OAI compliant repositories to improve the visibility of local scholarship.

The literature on the problems of improving visibility and access for locally-produced scholarship focuses less than it perhaps it might on repository-based open access solutions to problems of information flow in scholarly discourse. Yet, whether developed by single institutions or through collaborative efforts, even small institutional repositories demonstrate the benefits of Willinsky's "publishing systems that can be installed and controlled locally, while offering a global presence.” ${ }^{153}$ Set up to comply with established open access standards, they can make local scholarship not only more visible, but readily available to anyone who will benefit from access to it. In accomplishing those goals, they go far toward fulfilling the requirements of the access principle and promoting what Colin Darch has called "the establishment of an equitable world information order, based on entrenched principles of full disclosure and free flow." "154

${ }^{152}$ See Peter Suber, “Journals: Please Post Your Access Policies,” SPARC Open Access Newsletter, Nov. 2, 2004, http://www.earlham.edu/ peters/fos/newsletter/1102-04.htm\#postpolicies.

${ }^{153}$ Willinsky, supra note 1, at 104-105.

${ }^{154}$ Darch, supra note 15, at 12. 